\title{
Mengembalikan Image Pariwisata Lombok Paska Bencana
}

\author{
Restoring Post-Disaster Lombok Tourism Image
}

Oleh:

\author{
Menur Kusumaningtyas ${ }^{1,2)}$; Cucu Hayati ${ }^{1)}$; M.Hatta Fahamsyah ${ }^{2,3}$ ) \\ STIE Mahardhika Surabaya1, Universitas Airlangga2, Universitas Pelita Bangsa ${ }^{3}$ \\ menur.kusumaningtyas@stiemahardhika.ac.id, cucu.hayati@stiemahardhika.ac.id,
}

\begin{abstract}
ABSTRAK
Era globalisasi dan teknologi berkontribusi terhadap bisnis pariwisata melampaui ekspor minyak, produk makanan sekaligus merupakan salah satu sumber pendapatan utama bagi banyak negara berkembang. Di bidang pelayanan, kekhasan pariwisata menampilkan dirinya sebagai industri utama untuk penggunaan dan inovasi teknologi. Tetapi di balik pertumbuhannya, muncul pula risiko iklim yang datang tanpa kompromi. Gempa Lombok merupakan awal dari rangkaian Gempa Lombok 2018 yang dipicu oleh aktivitas sesar naik di utara Lombok. Hal ini menelan banyak korban jiwa dan lebih dari 10.000 bangunan rusak. Berita kehancuran dan memukul pariwisata Lombok serta meneror wisatawan dalam merencanakan wisata ke Lombok, dengan cepat menyiarkan kabar hingga ke manca negara. Dampak ekonomi dari gempa, kerusakan hingga kerugian yang dialami pelaku usaha pariwisata dan pemulihan citra destinasi,membutuhkan pemulihan hinga bertahun-tahun. Makalah ini bermaksud untuk memperdalam kerusakan yang terjadi pada pulau Lombok, dengan menyarankan beberapa tindakan yang dapat meminimalkan efek dari bencana untuk menarik Kembali minat wisatawan sehingga memulihkan perekonomian Indonesia.
\end{abstract}

Kata kunci:

Manajemen krisis; Krisis Keselamatan dan Keamanan; Image Destinasi

\section{ABSTRACT}

The era of globalization and technology has contributed to the tourism business beyond the export of oil, food products and is one of the main sources of income for many developing countries. In the service sector, the specialty of tourism presents itself as a major industry for the use and innovation of technology. But behind its growth, there are also climate risks that come without compromise. The Lombok Earthquake was the beginning of the 2018 Lombok Earthquake series which was triggered by an upswing activity in the north of Lombok. This claimed many lives and damaged more than 10,000 buildings. News of the destruction and hit Lombok tourism as well as terrorizing tourists in planning tours to Lombok, quickly spread the news to foreign countries. The economic impact of the earthquake, the damage to the losses suffered by tourism business actors and the restoration of the image of the destination, requires years of recovery. This paper intends to deepen the damage done to the island of 
Lombok, by suggesting some actions that can minimize the effects of the disaster in order to re-attract tourists and thus restore the Indonesian economy.

Keywords: Crisis management; Safety and Security Crisis; destination

\section{PENDAHULUAN}

Pariwisata Lombok menawarkan beberapa tempat paling indah di Indonesia. Ditetapkannya Labuan Bajo sebagai destinasi prioritas pariwisata halal oleh Kementrian Pariwisata menjadi gerbang pariwisata di kawasan timur Indonesia karena keberadaan Taman Nasional Komodo. Saat ini, daerah tersebut memiliki empat program pembangunan infrastruktur sesuai dengan Peraturan Presiden Nomor 32 Tahun 2018 tentang tata cara operasional di Labuan Bajo dan Flores. Keempat program tersebut antara lain: 1) Pemetaan Kawasan Strategis Pariwisaa Labuan Bajo; 2) Mengembangkan Bandara Internasional Komodo; 3) Memasang 20 Mooring Bay Point di dalam kawasan Taman Nasional Komodo; 4) Membanbun Pengelolaan Sampah Terpadu Labuan Bajo (Kemenparekraf, 2021)

Sektor pariwisata Lombok ini telah tumbuh secara konsisten di dekade terakhir dengan periode dan pertumbuhan yang lebih lambat. Pada tahun 2017, wilayah tersebut memperkirakan jumlah wisatawan mancanegara sebanyak 1.750.000. Pada kenyataannya, jumlah kedatangan menurun menjadi 1.430.249. Sementara untuk wisatawan domestik masih mengalami peningkatan dari perkiraan 1.750.000 menjadi 2.078.654. Meskipun total jumlah wisatawan mengalami kenaikan dari perkiraan namun tidak mengalami kenaikan signifikan. Yaitu sekitar 8.903 wisatawan saja.
Angka turun di kedua wisatawan mancanegara dan domestik di tahun 2018, dari perkiraan 1.500 .000 untuk mancanegara turun menjadi 1.204.556. Sementara pada turis lokal dari 2.500.000 turun di angka 1.607.823. Seperti disebutkan di atas, Lombok hanya mengalami pergolakan besar berupa bencana alam di tahun 2018.

Selama ini kontribusi industri pariwisata di Kabupaten Manggrai Barat cukup besar terhadap peningkatan Pendapat Asli Daerah (PAD). PAD yang diterima pada tahun 2017 mencapai 125 miliar rupiah. Selain itu, pendapatan kabupaten juga mengalami peningkatan sebesar 4,76\% dibanding sebelumnya yang hanya sebesar 4,45\% pada tahun 2015 .

Sementara Lombok yang sudah dikenal terlebih dahulu sebagai wisata alam, keindahan lanskap, keragaman habitat alami, keberadaan beberapa gili, dan pasir keemasan menarik ribuan wisatawan setiap tahun. Pariwisata secara tradisional dianggap ideal dengan instrument wisata guna meningkatkan ekonomi daerah (Machado, L. P. et al., 2012) Tren peningkatan bencana alam di Indonesia terbukti diantaranya disebabkan oleh pemanasan global yang menyebabkan peningkatan dramatis dalam kerentanan infrastruktur pesisir dan pariwisata dataran rendah (Okuyama, 2018).

Dalam hal ini, terjadinya bencana sekaligus merebaknya pandemi menyebabkan kerugian kualitas sistem ekologi, diikuti oleh penurunan jumlah kedatangan wisatawan asing dan domestik. Saat ini, seiring dengan 
meningkatnya jumlah kasus dan risiko terutama terkait dengan bencana alam besar dan pandemi, secara proporsional lebih sulit untuk dicegah dan dikendalikan. Jumlah korban akibat covid19 yang semakin meningkat dan intensitas bencana alam menyoroti pentingnya mempelajari pariwisata pasca bencana untuk meningkatkan dan mempromosikan praktik manajemen risiko.

Penelitian tentang perilaku wisatawan dalam kerangka waktu pasca bencana perlu pengembangan (Okuyama, 2018). Yang perlu diketahui adalah membangun kembali citra destinasi wisata dinilai sangat mempengaruhi proses pengambilan keputusan wisatawan dalam melakukan perjalanan wisata. Karena wawasan wisatawan termasuk kesan terhadap suatu destinasi berupa review dari media sosial, memiliki pengaruh besar terhadap kunjungan. Semakin banyak studi mempelajari masalah manajemen krisis, semakin berperan dalam membantu daerah untuk skema perencanaan proaktif dan sistem reaktif (Prideaux, B., Laws, E., \& Faulkner, 2003). Namun, komponen kunci dari skema manajemen krisis terletak pada persepsi pengunjung. Dalam hal ini, analisis manajemen krisis menjadi perhatian karena bencana alam dan pandemi memiliki dampak yang besar pada wisatawan dengan efek luas pada perilaku dan keputusan berkunjung.

Sejalan dengan tren yang diamati di seluruh dunia, Lombok rentan terhadap bencana alam disusul oleh pandemi yang memukul perekonomian dunia (Kusumaningtyas, 2020) Menghadapi tantangan seperti itu pemerintah daerah mempertimbangkan untuk mengarahkan fokusnya pada pembangunan sistem perencanaan yang bertujuan untuk mengidentifikasi dan menilai potensi risiko.
Pariwisata memainkan peran penting dalam menciptakan lapangan kerja dan nilai tambah di Lombok, Labuan Bajo dan sekitarnya. Tingkat ketergantungan pada pariwisata membuat ekonomi kawasan sangat rentan secara eksternal dengan guncangan berupa "pergerakan pariwisata yang tidak menentu" (Ismeri, 2011).

Preferensi wisata ke daerah berbasis kepulauan tampaknya terkait dengan faktor-faktor seperti keragaman bentang alam, habitat alami (Komodo) dan minimal atau sama sekali tidak mengandung risiko dan kegagalan hingga mengancam jiwa. Keberanian mengambil risiko diperlukan oleh setiap pelaku usaha tetapi memiliki tingkat yang berbeda (Wulandari \& Deliabilda, 2020). Studi ini menganalisis pengalaman terkini dari sektor pariwisata di Lombok dalam menghadapi bencana alam besar.

\section{METODE PENELITIAN}

Pariwisata adalah sektor ekonomi yang dominan di Lombok. Sektor ini diuntungkan dari pantai dan negeri seribu masjid yang menjadi pariwisata andalan yang dijual untuk menarik wisatawan yang 'bosan' dengan Bali, pulau tetangganya.

Penelitian ini menggunakan metode kuantitatif dengan studi pustaka untuk mengulas literatur yang berkaitan dengan topik yang sedang dianalisis. Berdasarkan kualitas-analisis konten dari berita utama dan laporan pers lokal terkemuka serta surat kabar internasional, peneliti pada tahap pertama, menggunakan analisa konten untuk menganalisis upaya yang dilakukan oleh otoritas lokal dalam memulihkan normalitas sesegera mungkin, dalam rangka meningkatkan citra positif daerah yang dimiliki oleh sejumlah potensi wisata. Tahap kedua, menawarkan gambaran singkat tentang 
industri pariwisata di Lombok. Tahap Ketiga, mengulas literatur yang berkaitan dengan topik yang sedang dianalisis, dan Pada tahap keempat memberikan rincian bencana alam 2018 dan melihat respon pemerintah daerah terkait krisis untuk mengurangi besarnya potensi dampak yang paling parah. Pada tahap kelima, merangkum penelitian dan menyajikan kesimpulan.

\section{HASIL PENELITIAN DAN PEMBAHASAN}

\section{Tinjauan Literatur}

Pariwisata muncul sebagai salah satu industri yang paling rentan terhadap bencana alam dan perubahan iklim. Di negara kepulauan seperti Indonesia, industri pariwisata rentan terhadap banyak risiko termasuk bencana alam, wabah penyakit tropis, iklim, peristiwa terkait perubahan. Selain itu, ada signifikan tren variasi yang tidak terduga dan tidak menentu dalam pola permintaan untuk berbagai macam alasan. Misalnya, jadwal perhelatan yang dibatalkan karena faktor cuaca dan ekonomi lokal dapat menjelaskan perubahan permintaan pasar.

Bencana alam telah didefinisikan sebagai "suatu peristiwa yang disebabkan oleh kekuatan alam seperti cuaca yang menyebabkan kerusakan signifikan pada lingkungan fisik dan dapat mengancam keselamatan manusia (Henderson, 2016) Soal keamanan, (Beattie, 1992) menulis bahwa pariwisata dan bencana alam memunculkan gambaran yang sangat berbeda dan melibatkan emosi serta membentuk cara berpikir pengunjung. Ketika memikirkan pariwisata, pengunjung membayangkan "kesenangan, relaksasi, tamasya, dan lingkungan yang indah" (Beattie, 1992) Senada dengan itu, (Santana, 2003) merujuk bahwa wisatawan tidak terbiasa untuk berpikir tentang pariwisata dan bencana alam secara bersamaan. Pariwisata membangkitkan perasaan senang, relaksasi, dan kenyamanan, sementara bencana alam berkaitan erat dengan kesusahan, kematian, ketakutan, kecemasan, trauma, dan panic. Karena itu, daerah yang dilanda bencana tampaknya tidak dianggap sebagai tempat liburan yang ideal. Jika banyak turis manca negara terpengaruh dalam satu atau lain cara oleh bencana alam saat berlibur, dampak negatifnya terhadap citra yang disampaikan ke luar negeri mungkin cukup serius dan sulit untuk dipulihkan.

Pasca bencana alam, destinasi wisata didesak untuk membangun kembali infrastruktur, lingkungan, fasilitas dan masyarakat. Namun, pada tahap pascapemulihan, pemasaran komunikasi yang bertujuan untuk mendapatkan kembali pangsa pasar adalah kuncinya. Dalam hal ini, pemasaran berupa kampanye sangat penting untuk mendukung upaya kawasan untuk memulihkan dan mengubah persepsi pelanggan yang salah. Dalam hal ini, penilaian profil pengunjung dalam hal respon, sikap dan afektif harus dilakukan sesegera mungkin untuk mengumpulkan informasi yang akurat dan terkini. Penting untuk mempertimbangkan bahwa industri pariwisata bergantung pada persepsi keselamatan, sistem operasional yang lancar dan prediktabilitas (Ritchie, 2008). Risiko mempengaruhi perilaku dan harapan wisatawan.

Bencana alam mempengaruhi tingkat keamanan yang dirasakan dan menjadi alasan utama untuk menguraikan langkahlangkah pengendalian risiko yang tepat. Alasan utama untuk mengendalikan risiko dan merencanakan dalam langkahlangkah mitigasi lanjutan terletak pada kemampuan untuk mengelola dampak krisis. Pada kenyataannya, besarnya dampak bencana alam besar pada industri 
pariwisata sangat ditentukan oleh respon wisatawan. Turis berhak atas fleksibilitas dalam memutuskan langkah selanjutnya: apakah akan mengunjungi atau tidak. Oleh karena itu, diperlukan cara untuk mengurangi sebagian besar dampak dari bencana, tidak peduli seberapa besar bencana yang mungkin muncul pada awalnya.

Dalam beberapa tahun terakhir, ketakutan para pelancong didorong oleh beberpa bencana alam seperti dibatasi oleh Tsunami Samudra Hindia pada tahun 2004 yang menghantam Aceh dan sekitarnya. Sebagai buntut dari peristiwa tersebut,sejumlah penelitian menganalisis pemulihan pascabencana dan strategi perencanaan (Ritchie, 2008). Media menjadi peran kunci dalam membentuk citra daerah yang terkena bencana (Sharpley, 2005). Berita di media dapat meningkatkan kesadaran masyarakat. Liputan yang seimbang dan informatif sejak awal membantu masyarakat lokal memahami keadaan.

Biasanya, insiden dengan korban tewas yang tinggi cenderung menarik minat khalayak dan liputan media. Ironisnya, berita itu mengubah aliran peristiwa yang tidak terkendali menjadi peluang untuk menarik pemirsa baru.

Sebagaimana yang diamati oleh McClure (2012) bahwa psiko teknologi, berita kabel 24 jam sekarang mengubah semua bencana alam besar menjadi tontonan kehancuran yang menguntungkan (McClure, 2012)

Bagaimanapun, untuk mempelajari reaksi pengunjung sangat penting untuk mengidentifikasi pola tingkah laku. (Itzhaky, H., Kissil, K., \& Weiss-Dagan, 2016) berdasarkan analisis kualitatif dari pengalaman yang dirasakan oleh sekelompok backpacker, yang sedang bepergian ke Nepal pada saat gempa bumi, mengidentifikasi empat tema utama: gejolak emosional, pemulihan, cepat dan tanggap dalam tindakan serta koneksi ke tentara. Sementara sebagian besar orang yang diwawancarai memahami krisis secara emosional pada awalnya, pada tahap kedua, responden mencari cara-cara untuk mengatasi situasi di lapangan secara efektif berdasarkan pemecahan masalah strategi (komunitas tindakan, analisis pengalaman masa lalu). Sebuah penilaian positif terhadap citra destinasi berperan penting dalam hal ini.

Bigne dkk. (2001) menganggap bahwa citra destinasi individu adalah subjektif, ambigu dan immaterial oleh alam karena terkait erat dengan interpretasi individu wisatawan tentang "kenyataan" yang dibuat oleh wisatawan. Citra suatu destinasi di benak pengunjung adalah sebagian besar bersifat subjektif karena didasarkan terutama pada persepsi daripada atribut, yang terutama benar ketika tidak ada kunjungan yang benarbenar terjadi. Ada sebuah konsensus luas bahwa citra diperparah oleh komponen kognitif dan afektif. (Bigné, E., Sánchez, M., \& Sánchez, 2001)

Baloglu, S., \& McCleary

menegaskan bahwa komponen kognitif berhubungan dengan keyakinan atau pengetahuan sebelumnya tentang atribut tujuan, sedangkan afektif adalah komponen yang berhubungan dengan perasaan terhadap atau keterikatan emosional dengan karakter yang menonjol. Beerli, A., \& Martín (2004) menemukan bahwa sosio-demografis latar belakang wisatawan memberikan pengaruh besar pada kognitif individu dan penilaian afektif dari keseluruhan gambar. Secara keseluruhan, gambaran keseluruhan destinasi terbentuk dalam pikiran pengunjung hasil dari kombinasi aspek kognitif dan afektif dengan pengalaman dan kunjungan sebelumnya sehingga memengaruhi citra destinasi. 
Citra destinasi dikondisikan oleh informasi yang berkaitan dengan sejarah, fakta politik, ekonomi dan sosial dan juga bencana alam yang akan menyebabkan penilaian kembali dari gambar awal yang disimpan dalam pikirannya. Selanjutnya, nilai-nilai yang dibagikan kepada setiap wisatawan berpotensi akan mempengaruhi citra keseluruhan dari setiap tujuan wisata, dengan menawarkan filter perhatian selektif. Apalagi negara asal pengunjung berpotensi mempengaruhi citra dalam pikiran pengunjung (de Almeida \& Machado, 2019)

\section{Analisis}

Gempa bumi Lombok yang terjadi pada Agustus 2018 adalah sebuah gempa darat berkekuatan magnitudo 7 yang melanda Pulau Lombok, Indonesia pada tanggal 5 Agustus 2018, pukul 19:46 WITA merupakan gempa utama dari rangkaian gempa bumi di Pulau Lombok.

Pada tahun 2018 ini, Lombok di guncang gempa dua kali. Gempa pertama yakni gempa bumi tektonik yang terjadi pada tanggal 29 Juli 2018 pada pukul 05.47 Wib. Gempa tersebut terletak di darat pada koordinat 116,5 derajat BT dan 8,4 derajat LS, berjarak sekitar $47 \mathrm{~km}$ timur laut kota Mataram, dengan kedalaman $24 \mathrm{~km}$ dan kekuatan atau magnitudo mencapai 6,4. Gempa ini tidak menimbulkan tsunami karena lokasi pusat gempa bumi terletak di darat.(Kompas.com, 2018)

Bencana Lombok mendapat perhatian dunia sebagai peristiwa langka oleh pers. Dampak media di Indonesia, mengundang simpati dan banjirnya bantuan kepada keluarga korban. Setelah bencana alam, pihak berwenang bekerja keras untuk memulihkan dan membangun kembali sarana dan prasarana utama.

Pemerintah daerah menghimbau pemasaran ekstensif untuk mengurangi dampak negatif pada opini publik. Pada akhirnya, mereka berhasil menanamkan rasa normal. Jalan-jalan dibersihkan dari puing-puing dalam beberapa hari. Pada hari berikutnya, operasi pemulihan dan pembersihan berlangsung baik dari aparat pemerintah, relawan dan masyarakat sipil. Pemerintah setempat berhasil memulihkan kondisi normal sesegera mungkin, di sebagian besar wilayah. Layanan penting seperti listrik dan layanan air dipulihkan, termasuk layanan telekomunikasi. Bandara, pelabuhan dan kawasan wisata utama tetap beroperasi dan siap menyambut pengunjung.

Bertujuan untuk menarik wisatawan kembali, pemerintah daerah menerapkan serangkaian langkah-langkah untuk merevitalisasi industri pariwisata. Salah satu pelaku bisnis perhotelan terkemuka merekomendasikan kampanye pemasaran agresif berdasarkan harga.

Untuk meningkatkan daya saing industri pariwisata, pemerintah daerah telah melakukan sejumlah inisiatif untuk menarik dan meningkatkan pengalaman pengunjung dan untuk memenuhi kebutuhan pengunjung. Namun, barubaru ini Pulau Nusa Tenggara kerap ditampilkan dalam berita karena promosi wisata Labuan Bajo yang mendapatkan pengakuan internasional sebegai wisata yang menerapkan wisata halal.

\section{Pembahasan}

Pada dasarnya, pemerintah daerah mengadopsi pendekatan ganda: (a) baik dengan bekerja sama dengan media, berdasarkan wawancara, konferensi pers dan kesiapan serta kesediaan untuk menanggapi salah satu dari pertanyaan wartawan dan untuk memberikan informasi atau (b) menggunakan strategi pengendalian informasi guna mengecilkan keseriusanperistiwa yang terjadi. 
Peneliti akan memusatkan perhatian pada strategi pengendalian informasi. Pendekatan pertama terletak pada mengabaikan krisis (dengan berpura-pura seolah-olah tidak terjadi apa-apa) dengan mempromosikan wisata Lombok dan Labuan Bajo ke manca negara. Sehingga geliat promosi ini akan berdampak pada geliat aktivitas pariwisata (Benoit, 1997).

Tidak dipungkiri, pihak berwenang di Lombok sepenuhnya mengakui sejauh mana tragedi itu di tingkat domestik. Tetapi, untuk memulihkan kembali pariwisata yang menjadi mata pencaharian utama masyarakat Lombok, pemerintah dan stakeholeder perlu mengalihkan fokus ke beberapa area di Lombok sambil menunjukkan upaya yang dilakukan untuk membersihkan dan mengamankan semua area di sekitar aset pariwisata utama untuk mengecilkan masalah. Sehingga akan tampak, Lombok siap untuk menyambut turis. Pendekatan lain untuk menangani krisis terletak pada mengecilkan dan mengurangi dampak krisis dan bahkan mendorong pemulihan dini dengan menggambarkan peristiwa tersebut sudah ditangani dengan baik dalam hal kerusakan, hilangnya nyawa dan cedera. Dalam beberapa kasus, memang tidak mungkin mengabaikan atau membatasi pentingnya krisis industri pariwisata.

Tindakan pengendalian kerusakan sebagai alat informasi kerap digunakan oleh pejabat saat berhadapan dengan wartawan yang kerap mencecar pemerintah dengan isu-isu yang mengganggu (Bonn, M., Joseph, S., \& Dai, 2005). Varian lain dari pendekatan wisatawan adalah dengan menggambarkan krisis sebagai hal yang tidak relevan bagi wisatawan, minim risiko atau konsekuensi bagi warga negara asing (Avraham, 2016). Pemerintah setempat sebaiknya menggunakan pendekatan ini sampai batas tertentu. Namun, di bidang kontrol informasi teknik, pemerintah perlu mengakui sepenuhnya krisis guna membantu membangun citra transparansi dan kejujuran, yang terjadi di Lombok. Hal ini juga menjadi strategi komunikasi pada penyampaian informasi ke luar negeri terkait perubahan dan inisiatif yang dilakukan untuk meminimalkan semua kesulitan yang dirasakan beserta langkahlangkah yang diambil untuk memantapkan awal era baru berdasarkan perencanaan kota, manajemen risiko, langkah-langkah, investasi dalam infrastruktur yang bertujuan untuk meminimalkan dampak di masa yang akan depan terhadap bahaya alam, dll. (Avraham, 2015).

Di lain kasus, otoritas lokal dapat menggunakan peristiwa sorotan untuk menciptakan berita dan mengalihkan perhatian media internasional dari penggambaran negatif ke positif memberikan contoh mengubah liabilitas menjadi aset, dengan mengubah bahaya dan menjadi pengalaman wisatawan yang tertarik menyaksikan awal era baru dan new normal (Avraham, 2015)

Dalam hal geografis, sangat mungkin mempromosikan Lombok yang terletak di Nusa Tenggara Barat dengan pesona pantai dan Gilinya. Termasuk didalamnya kearifan budaya suku Sasak yang masih kental. Di sejumlah kasus, masalah citra berasal dari prasangka, generalisasi dan stereotip, yang mungkin tidak dapat diperbaiki karena image cenderung tanpa melakukan ekspansi perubahan (Mansfeld, Y., \& Winckler, 2015). Jurnalis lokal dapat menargetkan pembaca tertentu untuk meningkatkan jumlah kedatangan alih-alih memilih strategi pengendalian kerusakan. Peran warga lokal dalam mepromosikan pariwisata daerahnya mulai digalakkan dengan memberikan review melalui media sosail atau vlog yang diunduh ke dalam 
portal You Tube yang kini menjadi konsumsi anak muda dalam menemukan berita terkini melalui gambar, tidak hanya tulisan. Dengan memberitakan ciri khas daerah, panorama alam Lombok, sejarah peradaban serta hubungan kekerabatan dengen Bali di masa lampau, memungkinkan untuk menarik minat wisatawan. Pendekatan yang lebih umum terletak pada pengembangan atau dengan membuka ceruk pasar baru.

Dalam hal ini, upaya diarahkan pada promosi segmen pasar baru seperti golf, trekking Gunung Rinjani yang mnejadi gunung hutan tertinggi nomor dua di Indonesia setelah Kerinci, wisata pedesaan, ekowisata dan lainnya. Ada konsensus bahwa pariwisata budaya tidak terpengaruh oleh krisis lokal. Di Lombok, alih-alih mempromosikan secara tradisional, pemerintah daerah mulai mempromosikan dan menggelar serangkaian acara budaya. Kampanye yang berhasil adalah kampanye yang dirancang untuk mempromosikan budaya daerah, karena diyakini bahwa budaya daerah memiliki nilai mendalam dan berkesan.

Pada akhirnya, Lombok berhasil menghindari konsekuensi yang buruk dari Gempa bumi 2018. Kampanye dan pemulihan citra mampu menangkal sebagian besar citra negatif apa pun yang disampaikan ke luar negeri melalui media.

\section{KESIMPULAN}

Wilayah Lombok yang eksotik dengan gilinya, beberapa tahun belakang berada di bawah tekanan dalam mengatasi jumlah ancaman eksternal berupa bencana alam, disusul wabah pandemi yang secara otomatis mematikan pariwisata. Lombok memberikan contoh instruktif dengan terus-menerus berupaya dalam menarik minat wisatawan, baik asing maupun domestik. Upaya ini (sebelum pandemi) mengalami pertumbuhan dalam hal kedatangan, penginapan, dan pendapatan. Industri pariwisata Lombok dipaksa untuk menangani isu-isu kompleks yang berkaitan dengan bencana alam. Karena kuantitas dan kualitas keunggulan kompetitif sektor ini, industri pariwisata ini mengalami pemulihan yang signifikan. Terbukti dengan dan tingkat permintaan yang tinggi terhadap wisata Lombok.

Operator perlu memasukkan ke dalam proses pengambilan keputusan dan strategi pelajaran perencanaan yang dipetik dari gempa bumi 2018. Sejumlah strategi dapat berhasil diterapkan jika dampak bencana alam natural terletak pada kisaran yang dapat diterima. Bencana yang mengganggu akan menuntut tindakan lebih lanjut, yang seharusnya mendorong operator di daerah untuk mengadopsi strategi "siap bencana".

Penelitian selanjutnya diharapkan dapat menindaklanjuti penelitian ini agar diperoleh temuan yang lebih komprehensif. Selain itu, juga perlu ada telaah mendalam baik secara kualitatif maupun kuantitatif yang dapat dijadikan referesi atau landasan dalam membuat kebijakan.

\section{DAFTAR PUSTAKA}

Avraham, E. (2015). Destination image repair during crisis: Attracting tourism during the Arab Spring uprisings. Tourism Management, 47, 224-232. 
Avraham, E. (2016). Destination marketing and image repair during tourism crises: The case of Egypt. Journal of Hospitality and Tourism Management, 28, 41-48.

Baloglu, S., \& McCleary, K. (1999). A model of destination image formation. Annals of Tourism Research, 35(4), 11-15.

Beattie, M. (1992). The effect of natural disasters on tourism a study of Mount Saint Helens and Yellowstone National Park. Master thesis. http:/ / scholarworks.rit.edu/theses/7428/

Beerli, A., \& Martín, J. (2004). Tourists' characteristics and the perceived image of tourist destinations: A quantitative analysis - A case study of Lanzarote, Spain. Tourism Management, 25, 623-636.

Benoit, W. (1997). Image repair discourse and crisis communication. Public Relations Review, 23(2), 177-187.

Bigné, E., Sánchez, M., \& Sánchez, J. (2001). Tourism image, evaluation variables and after purchase behaviour: Inter-relationship. Tourism Management, 22, 607-616.

Bonn, M., Joseph, S., \& Dai, M. (2005). International versus domestic visitors: An examination of destination image perceptions. Journal of Travel Research, 43(3), 294-301.

de Almeida, A. M. M., \& Machado, L. P. (2019). Madeira Island: Tourism, natural disasters and destination image. In Contributions to Economics (pp. 285-301). Physica-Verlag. https:/ / doi.org/10.1007/978-3-030-02662-2_14

Henderson, J. C. (2016). Halal food, certification and halal tourism: Insights from Malaysia and Singapore. Tourism Management Perspectives, 19, 160-164. https:// doi.org/10.1016/j.tmp.2015.12.006

Ismeri, E. (2011). Growth factors in the outermost regions, Final report Vol. II,. European Commission.

Itzhaky, H., Kissil, K., \& Weiss-Dagan, S. (2016). International tourists' reactions to a natural disaster: Experiences of the 2015 earthquake in Nepal among Israeli travelers. Journal of Trauma Stress, 29(6), 522-529.

Kemenparekraf. (2021). Selamat datang di Website Kemenparekraf. https:/ / kemenparekraf.go.id/

Kompas.com. (2018). Magnitudo 7,0 Jadi Gempa Terbesar Dalam Sejarah Lombok. https:/ / regional.kompas.com/read/2018/08/08/14024381/magnitudo-70-jadigempa-terbesar-dalam-sejarah-lombok?page=all

Kusumaningtyas, M. (2020). NEW NORMAL: PELAJARAN YANG DIPETIK DARI COVID19 UNTUK USAHA PERHOTELAN YANG BEROPERASI DI JAWA TIMUR. In Ecopreneur.12: Journal Economic and Business (Vol. 3, Issue 2). https://doi.org/10.2345/E12.V3I2.775

Machado, L. P., \&, \& A., A. (2012). Natural disasters in touristic destinations: The case of Portuguese Islands. (B. Raskovi). Hauppauge, NY: Nova Science Publishers. (Chapter ID: _9303_ 2012).

Mansfeld, Y., \& Winckler, O. (2015). Can this be spring? Assessing the impact of the "ArabSpring" on the Arab tourism industry. Tourism: Znanstveno-Strucni Casopis, 63(2), 205-223.

McClure, K. (2012). Media coverage of natural disasters: Pentadic cartography and the case of the 1993 great flood of the Mississippi. - KB Journal, 8 (1, Spring 2012 Special. 
Okuyama, T. (2018). Analysis of optimal timing of tourism demand recovery policies from natural disaster using the contingent behavior method. Tourism Management, 37-54.

Prideaux, B., Laws, E., \& Faulkner, B. (2003). Events in Indonesia: Exploring the limits to formal tourism trends forecasting methods in complex crisis situations. Tourism Management, 24(4), 475-487.

Ritchie, B. (2008). Tourism disaster planning and management: From response and recovery to reduction and readiness. Current Issues in Tourism, 11, 315-348.

Santana, G. (2003). Crisis management and tourism: Beyond the rhetoric. Journal of Travel and Tourism Marketing, 15, 299-231.

Sharpley, R. (2005). The Tsunami and tourism: A comment. Current Issues in Tourism, 8, 344349.

Wulandari, A., \& Deliabilda, S. A. (2020). Keberanian Mengambil Risiko Bisnis pada Mahasiswa Ekonomi dan Bisnis. Jurnal Pengembangan Wiraswasta, 22(3), 217. https://doi.org/10.33370/jpw.v22i3.494 